\title{
Intralaminar Nucleus
}

National Cancer Institute

\section{Source}

National Cancer Institute. Intralaminar Nucleus. NCI Thesaurus. Code C32878.

Any one of the many cell groups located in the internal medullary lamina of the thalamus. 